\title{
DEFINING RELIGION: OF GOD, THE CONSTITUTION AND THE D.A.R.
}

The words "religion," "religious belief" and "religious organization" are common in American law. The outcome of a variety of cases hinges upon the definition of these words. State statutes exempt religious organizations from property and sales taxes, ${ }^{1}$ and the question arises whether a given organization is "religious" so as to qualify for these exemptions. ${ }^{2}$ Federal law exempts from the draft as conscientious objectors those whose religious beliefs oppose war, ${ }^{3}$ but the courts must determine whether an individual's beliefs are "religious" so as to exempt him. 4 In addition to exempting the ordinary income of religious organizations, ${ }^{5}$ the Internal Revenue Code exempts churches from taxes on unrelated business income. ${ }^{6}$ The Code exempts from the taxable

I See, e.g., CAL. Const. art. XIII, § 11/2; Ill. Rev. StAT. ch. 120, 500.2 (1963); Mo. Code art. 81, § 9 (1957); NEb. Rev. Stat. ch. 77, § 202(3) (1943). All fifty states have such exemptions in some form. See PFeffer, Church, State and Freedom 184 (1953); TORPEy, JUdicial Doctrines of Religious Rights in AMERICA 196 (1948); Van Alstyne, Tax Exemption of Church Property, 20 OHı Sr. L.J. 461, 462 (1959). Congress exempts churches from District of Columbia property taxes. See D.C. CoDE $\S 47-801$ (a) (1961).

2 For a case holding property owned by a Masonic order taxable because not devoted to religious uses, see Masonic Bldg. Ass'n v. Town of Stamford, 119 Conn. 53, I74 Atl. 301 (1934). But see Ancient \& Accepted Scottish Rite of Freemasonry v. Board of County Comm'rs, 122 Neb. 586, 241 N.W. 93 (1932), exempting such property. For cases exempting Secular Humanists, see Washington Ethical Soc'y v. District of Columbia, 249 F.2d 127 (D.C. Cir. 1957); Fellowship of Humanity v. County of Alameda, 153 Cal. App. 2d 673, 315 P.2d 394, hearing denied, 1 Giv. No. 17176 (Cal. Sup. Ct., Nov. 5, 1957) (4-3 decision).

3 "[No] person ... [is] subject to combatant training and service in the armed forces of the United States who, by reason of religious training and belief, is conscientiously opposed to participation in war in any form." Universal Military Training and Service Act, 62 Stat. 612 (1948), 50 U.S.C. App. § 456(j) (1958).

4 For a case holding that one need not believe in deity to have a religious belief under the predecessor statute, see United States v. Kauten, 133 F.2d 703 (2d Cir. 1943). Contra, Berman v. United States, 156 F.2d 377 (9th Cir.), cert. denied, 329 U.S. 795 (1946). The present statute defines "religious training and belief" as "an individual's belief in a relation to a Supreme Being involving duties superior to those arising from any human relation, but does not include essentially political, sociological, or philosophical views or a merely personal moral code." Universal Military Training and Service Act, 62 Stat. 613 (1948), 50 U.S.C. App. § 456(j) (1958). There has been some difficulty in applying even this definition. See, e.g., United States v. Jakobson, 325 F.2d 409 (2d Cir. 1963), aff'd, 85 Sup. Ct. 850 (1965).

5 INT. REV. CODE OF 1954, § 501(a), (c)(3).

- INT. REv. CODE of 1954, § 511; Treas. Reg. § 1.511-2(a)3 (1963). 
income of a "minister of the gospel" the rental value of a house provided as part of his compensation.7 Is a secular humanist group leader or the head of the Black Muslims a "minister of the gospel"?s It is the policy of most prison administrations to encourage inmates' religious activities, ${ }^{9}$ but it must be determined which groups are religious so that their adherents be accorded the same privileges as followers of traditional faiths. ${ }^{10}$

The first amendment forbids the enacting of any "law respecting an establishment of religion, or prohibiting the free exercise thereof . ..."11 The courts have tried to define just what "religion" means in this context. A recent California case held that the first amendment compelled reversal of the conviction of certain Navajo Indians for the consumption of peyote, which is a required part of their "religious" ritual.12 A similar question has arisen in the cases of fortune-tellers and members of snakehandling sects, convicted under statutes prohibiting such practices, who argued for reversal of their convictions on the grounds that their practices were part of a religious ritual.13 What determines whether these groups are "religious" so as to bring their practices under the protective wing of the first amendment?

7 INT. REv. CODE of 1954, § 107.

8 One whose duties constitute the conduct of religious worship or the ministration of sacerdotal functions according to the tenets of his faith is included in the term. 26 C.F.R. \& 1.107-1 (Supp. 1964). See Rev. Rul. 58-221, 1958-1 Cum. Bul.. 53, which applied this definition and included a Jewish Community Center rabbi in the exemption. But see Rev. Rul. 61-213, 1961-2 Cum. Butr. 27, excluding a cantor at a Jewish Community Center because he was not ordained by a theological seminary, even though he led religious worship and performed sacerdotal functions.

9 See In re Ferguson, 55 Cal. 2d 663, 361 P.2d 417, 12 Cal. Rptr. 753, cert. denied, 368 U.S. 864 (1961). A New York statute declares prisoners to be "entitled to the free exercise and enjoyment of religious profession and worship ...." N.Y. CorRECTION LAW $\S 610,10$ MCKInNEy's Consol. Laws $\S 610$ (1944). See also Drinan, Religion, The Courts, and Public Policy 21-23 (1963).

10 Holding that the Black Muslims must be accorded the privileges of a religion, see, e.g., Sostre v. McGinnis, 334 F.2d 906 (2d Cir.), cert. denied, 85 Sup. Ct. 168 (1964); Banks v. Havener, 234 F. Supp. 27 (E.D. Va. 1964); Brown v. McGinnis, 10 N.Y.2d 531, 180 N.E.2d 791, 225 N.Y.S.2d 497 (1962) (3-1-3 decision). But for dicta suggesting that this group is not a religion, see Cleggett v. Pate, 229 F. Supp. 818 (N.D. Ill. 1964); In re Ferguson, supra note 9.

11 U.S. CONST. amend. I. This prohibition applies not only to Congress but also to the states through the fourteenth amendment. See Abington School Dist. v. Schempp, 374 U.S. 203, 215-16 (1963), and cases cited there. Schempp held that a state may not require reading from the Bible or the Lord's Prayer in public schools.

12 People v. Woody, 61 Cal. 2d 716, 394 P.2d 813, 40 Cal. Rptr. 69 (1964).

13 See McMasters v. State, 21 Okla. Crim. 318, 207 Pac. 566 (1922), affirming the conviction of a spiritualist fortune-teller even though she claimed merely to be practicing her religion. Holding that snake-handling may be regulated even though a part of religious ritual because of the overriding state interest in public safety, see Lawson v. Commonwealth, 291 Ky. 437, 164 S.W.2d 972 (1942); State v. Massey, 229 N.C. 734,51 S.E.2d 179 (1949); Kirk v. Commonwealth, 186 Va. 839,44 S.E.2d 409 (1947). 
These are but a few examples of areas in which the problem of definition arises. As demonstrated by the Supreme Court decision in United States $v$. Seeger, ${ }^{14}$ the problem is a recurring one. It is the object of this inquiry to examine critically the definitions applied by the courts and to suggest one which reconciles legislative intent with constitutional requirements.

\section{The Evolution of the Defintion -}

Because defining "religion" would appear to be a problem of statutory construction involving the particular legislature's intent in each statute where the word appears, one would expect definitions to vary among courts construing different statutes. This has not been the case.

Courts have usually construed religion to mean "one's views of his relations to his Creator, and to the obligations they impose of reverence for his being and character, and of obedience to his will."15 At an early date, however, a very few judges seemed dissatisfied with the requirement of belief in deity and hinted at a broader definition which would recognize belief in a supreme being to be a characteristic common, but not necessary, to religions. ${ }^{16}$

1485 Sup. Ct. 850 (1965).

15 Davis v. Beason, 133 U.S. 333, 342 (1890) (Field, J.), quoted frequently with approval, e.g., Gabrielli v. Knickerbocker, 12 Cal. 2d 85, 82 P.2d 391 (1938); Nicholls v. Mayor of Lynn, 297 Mass. 65, 7 N.E.2d 577 (1937); Kolbeck v. Kramer, 84 N.J. Super. 569, 202 A.2d 889 (1964). In his dissent in United States v. MacIntosh, 283 U.S. 605, 633-34 (1931), Mr. Chief Justice Hughes (Holmes, Stone and Brandeis, JJ., concurring) stated: "The essence of religion is belief in a relation to God involving duties superior to those arising from any human relation. . . . One cannot speak of religious liberty, with proper appreciation of its essential and historic significance, without assuming the existence of a belief in supreme allegiance to the will of God." See also People v. Deutsche Gemeinde, 249 Ill. 132, 136, 94 N.E. I62, I64 (1911); Sunday School Bd. v. McCue, 179 Kan. 1, 293 P.2d 234 (1956).

Few judicial decisions have been found which restrict "religion" more narrowly than requiring belief in deity. But see Scottish Rite Bldg. Co. v. Lancaster County, 106 Neb. 95, 182 N.W. 572 (1921) (overruled by Ancient \& Accepted Scottish Rite of Freemasonry v. Board of County Comm'rs, 122 Neb. 586, 241 N.W. 93 (1932)), which held that a Masonic order was not a religious organization because it was not sectarian and did not demand the exclusive "religious" allegiance of its members; Masonic Bldg. Ass'n v. Town of Stamford, 119 Conn. 53, 174 Atl. 301 (1934), holding that a Masonic group was not a religious organization because it was a secret organization not open to anyone willing to espouse its views, and because of the largely social basis for selecting members. In accord with the Stamford case, see In re Rathbone's Estate, 170 Misc. 1030, 11 N.Y.S.2d 506 (Sur. 1939); Fellowship of Humanity v. County of Alameda, 153 Cal. App. 2d 673, 706, 315 P.2d 394, 414 (1957) (dictum in dissent). Other limiting factors arise in determining whether a group is "primarily" or "exclusively" a religious organization, but these are statutory construction problems not likely to raise constitutional issues. See, e.g., Theta Xi Bldg. Ass'n v. Board of Review, 217 Iowa 1181, 251 N.W. 76 (1933).

16 "As to the word religion [used in the context of a bequest to a religious organization] ... in its primary sense ... it imports, as applied to moral questions, only a recognition of a conscientious duty to recall and obey restraining principles 
This viewpoint was clearly articulated in United States $v$. Kauten.17 The defendant was convicted under the 1940 Selective Service Act for refusing to submit to induction. He claimed exemption as a conscientious objector, defined by the act as "any person ... who, by reason of religious training and belief, is conscientiously opposed to participation in war in any form."18 Kauten was an atheist, was opposed to war because it solves no problems and felt that the draft was President Roosevelt's personal political scheme to decrease unemployment. The court affirmed the conviction because Kauten's refusal to serve was based on philosophical and political considerations rather than on religious beliefs. But the court went on to consider the definition of "religious" as used in the statute. In a much-cited dictum, Judge Augustus Hand equated conscience, an inner compulsion to "duty" which arises from a "sense of the inadequacy of reason as a means of relating the individual to his fellow-man and to his universe," with a religious impulse: "[A] response of the individual to an inward mentor, call it conscience or God ... is for many persons at the present time the equivalent of what has always been thought a religious impulse."10 Whereas prior cases focused on the particular dogma or creed of the group or individual seeking characterization as religious to determine whether that creed was similar enough to traditional creeds to be so classified, Kauten was perhaps the first major judicial opinion which focused instead on the psychological function of the religion for its adherent and the part it played in his life.

This approach, however, was not universally accepted. The Ninth Circuit disagreed with Kauten in Berman $v$. United States, ${ }^{20}$ where it dismissed Judge Hand's broad definition of religion as mere obiter and said that the Second Circuit cases ${ }^{21}$ relying on the Kauten dictum were in error. In affirming the conviction of a sincere humanistic pacifist for refusing to submit to induction, the seven-judge court held that "reli-

of conduct. In such sense we suppose there is no atheist who will admit that he is without religion." Estate of Hinckley, 58 Cal. 457, 512 (1881). See also Ex parte Jentzsch, 112 Cal. 468, 44 Pac. 803 (1896); In re Walker, 200 Ill. 566, 66 N.E. 144 (1902) (dictum); Board of Educ. v. Minor, 23 Ohio St. 211 (1872) (by implication from dictum); Knight's Estate. Friendship Liberal League's Appeal, $159 \mathrm{~Pa} .500,28$ Atl. 303 (1894).

17133 F.2d 703 (2d Cir. 1943).

18 Selective Service Act $\S 5(\mathrm{~g}), 54$ Stat. 887 (1940), 50 U.S.C. App. $\S 305(\mathrm{~g})$ (1940).

$19133 \mathrm{~F} .2 \mathrm{~d}$ at 708 .

20156 F.2d 377 (9th Cir.), cert. denied, 329 U.S. 795 (1946).

21 United States ex rel. Reel v. Badt, 141 F.2d 845 (2d Cir. 1944); United States ex rel. Phillips v. Downer, 135 F.2d 521 (2d Cir. 1943). These cases relied on Kauten in exempting from the draft as conscientious objectors "by reason of religious training and belief" philosophical humanists, who did not believe in deity but believed that war is immoral. 
gious" as used in the statute requires a concept of deity. ${ }^{22}$ Congress accepted the Berman definition and repudiated Kauten in the 1948 amendment to the Selective Service Act which explicitly defined "religious training and belief" to mean "an individual's belief in a relation to a Supreme Being involving duties superior to those arising from any human relation ... but does not include ... a merely personal moral code."'23

Since Kauten, the old definition requiring belief in a supernatural power has eroded. Two courts included nontheistic ${ }^{24}$ humanist societies within the statutory exemption from property taxes of buildings used exclusively for religious worship. ${ }^{25}$ These two cases have been cited with approval by the Supreme Court, which has clearly indicated in dictum that any belief regarding the ultimate questions of existence is religious. ${ }^{26}$ Until recently the most important case in this

22 "However, no matter how pure and admirable his standard may be, and no matter how devotedly he adheres to it, his philosophy and morals and social policy without the concept of deity cannot be said to be religion in the sense of that term as it is used in the statute." $156 \mathrm{~F} .2 \mathrm{~d}$ at 381.

2362 Stat. 609 (1948), 50 U.S.C. APP. \& 456(j) (1958). See S. REP. No. 1286, 80th Cong., 2d Sess. 14 (1948). Until recently, it had generally been conceded that Congress adopted the Berman definition. See, e.g., United States v. Seeger, 326 F.2d 846, 850-51 (2d Cir. 1964); United States v. Jakobson, 325 F.2d 409, 414 n.3 (2d Cir. 1964); Conklin, Conscientious Objector Provisions: $A$ View in the Light of Torcaso $v$. Watkins, 51 GEO. L.J. 252, 274-76 (1963). But in disposing of Seeger and Jakobson on appeal, the Supreme Court held that Congress, in the 1948 amendment to the act, did not intend to adopt Berman, but adopted Kauten insteadl 85 Sup. Ct. 850 (1965).

The same definition of "religious training and belief" (requiring belief in a supreme being) was used by Congress in the Naturalization Act, 66 Stat. 258-59 (1952), 8 U.S.C. § 1448(a) (1958).

24 For purposes of this comment, "theism" refers to all beliefs in one or more supreme or superhuman beings, and includes polytheism and deism. Nontheism is a belief system in which theism is not a principal element. This includes atheism and agnosticism.

25 See Washington Ethical Soc'y v. District of Columbia, 249 F.2d 127 (D.C. Cir. 1957); Fellowship of Humanity v. County of Alameda, 153 Cal. App. 2d 673, 315 P.2d 394 (1957). Although these cases reach the same result as Kauten, they do not utilize the Kauten approach of looking to the psychological function of an alleged religion instead of to the religion's doctrine or rituals.

26 "New Jersey cannot hamper its citizens in the free exercise of their own religion. Consequently, it cannot exclude individual Catholics, Lutherans, . . Non-believers, Presbyterians or the members of any other faith . . . Everson v. Board of Educ., 330 U.S. 1, 16 (1946) (Emphasis added.), permitting New Jersey to pay the bus fare of students attending Catholic schools. In McGowan v. Maryland, 366 U.S. 420 (1961), the Court upheld the constitutionality of Sunday closing laws. Mr. Justice Frankfurter indicated that religion is "man's belief or disbelief in the verity of some transcendental ideal and man's expression in action of that belief or disbelief." 366 U.S. at 466 (concurring). This was quoted with approval by Mr. Justice Brennan, concurring in Abington School Dist. v. Schempp, 374 U.S. 203, 234 (1963), where he discussed the constitutionality of exempting religious organizations from taxation and said: "And as among religious beneficiaries, the tax exemption or deduction can be truly 
regard was Torcaso: $v$. Watkins, ${ }^{27}$ where the Court unanimously struck down as invalid under the establishment clause a provision of the Maryland constitution which was applied to deny a Secular Humanist an appointment as notary public because he refused to declare a belief in God. The Gourt stated that belief in God is "a belief in some particular kind of religious concept."28 The first amendment forbids government to "aid those religions based on a belief in the existence of God as against those religions founded on different beliefs." 29 As a footnote to this statement, the Court said that "among religions in this country which do not teach what would generally be considered a belief in the existence of God are Buddhism, Taoism, Ethical Culture, Secular Humanism and others." 30

The importance of Torcaso's discussion of nontheism as religion is that it was on a constitutional level. The Court spoke of the first amendment prohibition against aiding theistic religions as opposed to nontheistic ones. The recent case of United States $v$. Seeger ${ }^{31}$ was much more explicit in including nontheism within the category "religion"-indeed, this is the holding of the case-but the Court's discussion concerned the construction of a particular statute and attempted to discern congressional intent in this legislation rather than requirements of the first amendment. The Universal Military Training and Service Act exempts from combatant status those who conscientiously object "by reason of religious training and belief." 32 Religious belief is defined as "an individual's belief in a relation to a Supreme Being involving duties superior to those arising from any human relation, but does not include essentially political, sociological, or philosophical views or a merely personal

non-discriminatory, available on equal terms to small as well as large religious bodies, to popular and unpopular sects, and to those organizations which reject as well as those which accept a belief in God." 374 U.S. at 301-02. The footnote to this statement cites Washington Ethical and Fellowship, stupra note 25.

27367 U.S. 488 (1961).

28 Id. at 495. (Emphasis added.)

29 Ibid.

30 Id. at 495 n.11. The Court could have said that because these groups do not teach belief in God they are philosophies and not religions. The reason the Court apparently accepted the contention of the American Ethical Union, which appeared as amicus curiae, that nontheistic belief constitutes religion entitled to first amendment protection, instead of drawing the line at belief in deity is not clear. It probably resulted from the Court's disinclination to inquire into, or to base any constitutional rights on, the content of one's beliefs. The spectre of such an inquiry as the first step towards an "inquisition" appears to influence the Court. See Brief for Appellant, pp. 8-11, and authorities discussed there.

3185 Sup. Ct. 850 (1965).

32 See notes 3, 4 supra. 
moral code." 33 Seeger declared his "skepticism or disbelief in the existence of God" " and said that his is "a "belief in and devotion to goodness and virtue for their own sakes, and a religious faith in a purely ethical creed. "34 The Court held that Seeger should be exempted from military service because his belief is "religious" and is a belief in "a relation to a Supreme Being" as Congress intended to use those terms.

In light of the history of the "Supreme Being" element of the statute's religious test, ${ }^{35}$ as well as its clear language, it seems that Congress did intend to limit conscientious objector status to those who believe in God as that term is commonly understood, and that the Court's talk of statutory construction and congressional intent was merely a device to avoid declaring the statutory definition of religion unconstitutional as discriminating against nontheistic religions. ${ }^{36}$ If one reads between the lines, Seeger is further authority that nontheism cannot be excluded from a constitutionally permissible definition of religion.

\section{God AND the Constitution}

These indications by the Supreme Court that nontheists are included within the first amendment guarantee of religious liberty raise the major constitutional difficulties in the definition of religion. For judicial purposes, definition is a matter of statutory construction. It is generally agreed that a word should be defined as it was understood by the legislators who enacted it. ${ }^{37}$ This approach might define the term to include only traditional religions because it is most likely that legislators enacting such statutes intended to aid only these groups. ${ }^{38}$ Another view is that the judicial task is to apply the words of the statute according to their present meaning. ${ }^{39}$ Under this approach the problem becomes: whose current definition shall the courts use. One prevalent view is that religion, "in the common understanding . . . means the formal recogni-

33 Universal Military Training and Service Act, 62 Stat. 618 (1948), 50 U.S.C. APP. § 456(j) (1958).

3485 Sup. Ct. at 854 .

35 See generally Conklin, supra note 23, at 269-76 (1963).

36 To this effect, see the first two paragraphs of Mr. Justice Douglas' concurring opinion, 85 Sup. Ct. at 865.

37 See, e.g., People ex rel. Fyfe v. Barnett, 319 Ill. 403, 150 N.E. 290 (1926). See also Levi, AN Introduction to Legal REAsoning 19-24 (1949); Frankfurter, Some Reflections on the Reading of Statutes, 47 CoLuMr. L. REv. 527, 536 (1947).

38 See Washington Ethical Soc'y v. District of Columbia, 84 Wash. L. Rptr. 1072, 1082 (D.C.T.C. 1956), rev'd, 249 F.2d 127 (D.C. Cir. 1957), quoted with approval in Fellowship of Humanity v. County of Alameda, 153 Cal. App. 2d 673, 704, 315 P.2d 394, 413 (1957) (dissent). Cf. First Unitarian Soc'y v. Town of Hartford, 66 Conn. 368, 375, 34 Atl. 89, 90 (1895).

39 See, e.g., Commonwealth v. Maxwell, 271 Pa. 378, 114 Atl. 825 (1921). 
tion of God as members of societies and associations." $\$ 0$ Contemporary dictionaries speak in terms of a supreme being, at least with respect to preferred definitions. ${ }^{41}$ On the other hand, some social scientists and modern "liberal" theologians use a broader definition. ${ }^{42}$ However, it is doubtful that the adoption of a professional avant-garde's radical experimental definition of an everyday term instead of the commonplace definition used by legislators and the populace is a proper judicial function. ${ }^{43}$ For these reasons, courts had tended to construe religion as requiring belief in deity.

Major difficulties arise, however, when a court's assessment of legislative intent commends to it a construction which conflicts with constitutional principles. It is axiomatic that in such a conflict the construction must yield to constitutional imperatives regardless of legislative intent. Thus, recent Supreme Court pronouncements indicating that religion is not to be equated with theism but is to be more broadly defined place courts between the horns of a dilemma: they must either ignore the legislative intent to aid traditional religions and construe the term broadly to avoid the constitutional difficulties raised by the narrower definition, 44 or they must declare the statute unconstitutional. Two recent conscientious objector cases point up this dilemma. In United States v. Jakobson, 45 in order to include the appellant's views within the statutory definition and avoid a constitutional question, the court of appeals defined "Supreme Being" so broadly as to exempt an individual whom Congress probably did not intend to exempt. In United States v. Seeger, a different panel of judges in the same circuit refused to stretch the

40 People v. Deutsche Gemeinde, 249 IIl. 132, 136, 94 N.E. 162, 164 (1911) (quoted frequently with approval). See also George v. United States, 196 F.2d 445, 452 (9th Cir.), cert. denied, 344 U.S. 843 (1952).

41 See, e.g., WebsteR's ThIRd NEw INTERnational Dictionary (Unabridged, 1961); The OXford English Dictionary (1933).

42 See United States v. Seeger, 85 Sup. Ct. 850 (1965); United States v. Jakobson, 325 F.2d 409, 415-16 (2d Cir. 1963), aff'd, 85 Sup. Ct. 850 (1965); Washington Ethical Soc'y v. District of Columbia, 34 Wash. L. Rptr. 1072 (D.C.T.C. 1956); RoBINson, Honest to God (1963); Robinson \& Edwards, The Honest to God Debate (1963); Stahmer, Defining Religion: Federal Aid and Academic Freedom, 1963 RELIGION AND THE PUBLIC ORDER 116, 131-33.

43 See, e.g., Frankfurter, supra note 37, at 536. But see United States v. Seeger, 85 Sup. Ct. 850 (1965), where the Court cited Paul Tillich, Bishop John A. T. Robinson and David Saville Muzzey in support of its definition of religion.

44 A statute should be construed so as to avoid constitutional difficulties. See United States v. Delaware \&. Hudson Co., 213 U.S. 366, 407-08 (1909); Harriman v. ICC, 211 U.S. 407, 422 (1908) (Holmes, J.); Matthews v. Matthews, 240 N.Y. 28, 34-35, 147 N.E. 237, 239 (1925) (Crane, J.). This is apparently what the Court did in United States v. Seeger, supra note 43.

45325 F.2d 409 (2d Cir. 1963), aff'd, 85 Sup. Ct. 850 (1965). 
words "Supreme Being" beyond recognition and instead held that belief in a supreme being is an unconstitutional criterion for exemption. ${ }^{46}$

It is in Seeger that the trend toward a broader definition of religion has culminated. The defendant had been convicted for refusing to submit to Army induction. He did not believe in a supreme being. The parties stipulated that he was "religious" within the Kauten definition, but the Government contended that he should be convicted because the 1948 amendment to the Selective Service Act expressly required belief in a supreme being as a condition for exemption. Seeger argued that Congress' definition of "religious belief" is unconstitutional in that it "establishes" theistic religions and arbitrarily discriminates against nontheistic religions. ${ }^{47}$ The Second Circuit reversed the conviction. It is reasonable to exempt religious objectors, said Judge Kaufman for the court, but to require belief in deity would unconstitutionally discriminate against nontheistic religions. In holding that this discrimination violates the due process clause of the fifth amendment, ${ }^{48}$ the court relied heavily on Torcaso $v$. Watkins, where the Supreme Court said that belief in deity is only one kind of religious concept. ${ }^{49}$ Torcaso's holding, that non-

46326 F.2d 846 (2d Cir. 1963), aff'd on other grounds, 85 Sup. Ct. 850 (1965). The Supreme Court heard the Seeger appeal together with United States v. Jakobson, 325 F.2d 409 (2d Cir. 1963) (holding that belief in an unknowable ultimate cause of all existence, "Godness," includes an objector in the statutory exemption from the draft) and Peter v. United States, 324 F.2d 173 (9th Cir. 1963) (approving the denial of exemption to one who does not believe in a supreme being as that term is commonly understood). The Court had before it in these cases the full range of judicial responses to the statutory definition: Peter upheld the statute's constitutionality and applied its terms literally to exclude a nontheist objector from the exemption; Jakobson avoided the constitutional problem by defining belief in a supreme being so broadly as to include one who does not believe in God in the ordinary sense of the term; and Seeger held the statutory definition unconstitutional.

Both Peter and Jakobson differ from Seeger in that they believe in the existence of forces external to and unknowable by man, whereas Seeger's belief is "internally derived," and assumes no power beyond man. See Brief for Appellant, p. 15, Peter v. United States, 85 Sup. Ct. 850 (1965). The Court said that this is irrelevant.

47 The trial court summarily dismissed Seeger's contention that the definition discriminates against nontheism, but discussed at length why it does not violate the establishment clause. United States v. Seeger, 216 F. Supp. 516, 520-22 (S.D.N.Y. 1963), citing Clark v. United States, 236 F.2d 13 (9th Cir.), cert. denied, 352 U.S. 882 (1956), and George v. United States, 196 F.2d 445 (9th Cir.), cert. denied, 344 U.S. 843 (1952). See also Etcheverry v. United States, 320 F.2d 873 (9th Cir.), cert. denied, 375 U.S. 930 (1963).

48 United States v. Seeger, 326 F.2d 846, 854 (2d Cir. 1964). On appeal, the Supreme Court rejected this view of the case and adopted the approach of Judge Friendly in Jakobson. The Court avoided the constitutional question by holding that despite the defendant's disbelief in God, his views do constitute religion as that term is used in the statute. 85 Sup. Ct. at 864 .

49367 U.S. 488,494 (1961). See discussion following note 27 supra. See also Conklin, supra note 23 , at $276-81$. 
theism is a form of religion protected by the first amendment, means that a definition of religion excluding nontheism is subject to attack on due process, equal protection and establishment clause grounds.

The court of appeals in Seeger did not cite authority for its position that legislation discriminating among religions in favor of theists violates due process, but stated the matter as a truism. However, this particular question has apparently not been decided before. ${ }^{50}$ The Supreme Court has said that a discrimination may be so arbitrary and unjustifiable as to violate due process, ${ }^{51}$ but because the standards in this area are vague, lower courts cannot apply the doctrine with certainty. The trend is apparently to prohibit legislative discrimination which is not reasonably related to a proper governmental objective. ${ }^{52}$

Recently, in Schneider $v$. Rusk, the Supreme Court held that the section of the Naturalization Act which deprived naturalized citizens of citizenship if they returned to their country of origin for a period of three consecutive years violated fifth amendment due process because no such restriction applied to native-born citizens. ${ }^{53}$ Every Justice participating in the decision agreed on the principle that the fifth amendment forbids arbitrary discriminations; ${ }^{54}$ the only disagreement between the majority and the dissenters was whether there was a reasonable basis for the discrimination at bar. Schneider, together with Bolling $v$. Sharpe,55 strongly supports the position that to discriminate among religions by excluding nontheists from the religious objector draft exemption is to violate fifth amendment due process. ${ }^{56}$

50 But see Fowler v. Rhode Island, 345 U.S. 67 (1953), holding that favoring some religions over others violates the first and fourteenth amendments. See also Niemotko v. Maryland, 340 U.S. 268, 272 (1951).

51 See Bolling v. Sharpe, 347 U.S. 497, 499 (1954). See also Detroit Bank v. United States, 317 U.S. 329, 337 (1943) (Stone, C.J.) (dictum); Currin v. Wallace, 306 U.S. I (1939) (Hughes, C.J.); Sterwart Machine Co. v. Davis, 301 U.S. 548, 584-85 (1937) (Cardozo, J.).

52 See Bolling v. Sharpe, supra note 51, where the Court held that racial segregation in District of Columbia public schools violates fifth amendment due process. Chief Justice Warren said: "Segregation in public education is not reasonably related to any proper governmental objective, and thus it imposes on Negro children of the District of Columbia a burden that constitutes an arbitrary deprivation of their liberty in vioIation of the Due Process Clause." Id. at 500. Cf. Pennsylvania R.R. v. Day, 360 U.S. 548, 554 (1959) (Warren, C.J., and Black and Douglas, JJ., dissenting).

53377 U.S. 163 (1964).

54 Id. at $168,170$.

55347 U.S. 497 (1954). See discussion supra note 52. Bolling and its progeny are considered to have held that fifth amendment due process includes an equal protection guarantee.

56 If it is unconstitutionally arbitrary under the fifth amendment to exempt theistic objectors from military service but not to exempt nontheistic religious objectors, it is surely unconstitutional to discriminate along these lines regarding exemption from federal taxation. 
A parallel attack based on the equal protection clause of the fourteenth amendment could be leveled against state legislation excluding nontheists from the benefits conferred on theistic religions. In holding that racial discrimination violates fifth amendment due process, the Supreme Court said that "the 'equal protection of the laws' is a more explicit safeguard of prohibited unfairness than 'due process of law, ..."5t Under this view, a discrimination between theism and nontheism which violates fifth amendment due process surely violates the broader fourteenth amendment guarantee of equal protection.58

Even if the arbitrary discrimination barrier could be surmounted, if nontheism is considered to be religion within the scope of the first amendment, a governmental definition excluding nontheists would surely be held unconstitutional as an establishment of one religion over others. Indeed, in Torcaso $v$. Watkins the restriction of the Maryland constitution that the petitioner could not be appointed a notary public unless he professed a belief in God was held unconstitutional under the establishment clause because it aided "those religions based on a belief in the existence of God as against those religions founded on different beliefs." 50 Torcaso makes it unquestionable that nontheism is included in the category of religion protected by the first amendment and that the establishment clause is transgressed when a statute favors theists over nontheists. This, together with the Court's oft-repeated statement

57 Bolling v. Sharpe, 347 U.S. 497, 499 (1954). The fifth amendment due process prohibition on arbitrarily discriminatory laws is similar to the equal protection guarantee of the fourteenth amendment. If legislation arbitrarily discriminates against nontheists, they are deprived of the protection the law gives to theists. A standard regarding arbitrariness stricter than that applied in fifth and fourteenth amendment situations generally may be read into applications of those amendments to religious discrimination. Board of Educ. v. Barnette, 319 U.S. 624 (1943), prohibited states from compelling Jehovah's Witnesses to salute the flag in school, on the ground of freedom of speech. The Court said that where the fourteenth amendment alone is involved state legislation will be upheld as not violative of due process if there is a "rational basis" for it; "but freedoms of speech and of press, of assembly, and of worship may not be infringed on such slender grounds. They are susceptible of restriction only to prevent grave and immediate danger to interests which the state may lawfully protect." Id. at 639. This statement is probably addressed to Mr. Justice Frankfurter's dissent, which stated that state legislation, even in this area, must be upheld if there is a reasonable basis for it. Id. at 647. Furthermore, Mr. Justice Black's dictum in Everson v. Board of Educ., 330 U.S. 1, 15 (1947), that the establishment clause prohibits preferring one religion over another, does not limit itself to situations where there is no reasonable basis for such a preference. This may imply that in the religious area, favoring one religion over another is presumptively arbitrary. (However, it should be noted that Mr. Justice Black was speaking in terms of the first amendment and did not refer explicitly to the fifth amendment.)

5s See Fowler v. Rhode Island, 345 U.S. 67, 69 (1953).

59367 U.S. 488,495 (1961). The Court declined to base the decision on the constitutional prohibition against "religious Test[s] ... as a Qualification to any Office or public Trust under the United States." Id. at 489 n.l. 
that the establishment clause prohibits favoring one religion over others, ${ }^{60}$ would appear to preclude any governmental definition of religion which excludes nontheism.

A definition is necessary, but the Supreme Court has set very narrow limits within which one is permissible under the first amendment. Torcaso clearly seems to prohibit a definition drawing the line between theists and nontheists. In addition, it appears that a definition should not be based on the content of an individual's beliefs. In United States v. Ballard," 61 the founder of the "I Am" sect was prosecuted for mail fraud. The Government contended that he intended to defraud his followers by telling them, among other things, that he had shaken hands with Jesus, had been selected as a divine messenger by Saint Germain and had the divine power of healing incurable diseases. His conviction was reversed by the circuit court, which said that the trial court erred in not submitting to the jury the question of whether any of the defendant's representations were in fact false. The Supreme Court reversed, holding that the trial court "ruled properly when it withheld from the jury all questions concerning the truth or falsity of the religious beliefs or doctrines of respondents" 62 because the first amendment prohibits such an inquiry:

60 "The 'establishment of religion' clause of the First Amendment means at least this: Neither a state nor the Federal Government can set up a church. Neither can pass laws which aid one religion, aid all religions, or prefer one religion over another." Everson v. Board of Educ., 330 U.S. 1, 15 (1947) (dictum), quoted with approval in Torcaso v. Watkins, 367 U.S. 488, $492-93$ (1961), and Abington School Dist. v. Schempp, 374 U.S. 203, 216 (1963).

Courts heretofore upholding the compatibility with the establishment clause of the conscientious objector definition requiring belief in deity rely on the Selective Draft Cases, 245 U.S. 366, 389-90 (1918), which dismissed as too obviously unsound to merit discussion the establishment clause attack upon the statute, which exempted only members of recognized pacifist religious sects. Because this was a wartime decision, and in light of the recent dicta referred to above, the unsoundness of an establishment clause attack on a restrictive objector exemption is no longer so obvious as it was in 1918. See KURLAND, RELIGION AND THE LAw 37-38 (1962). Recent thoughtful discussions reconcile religious objector exemptions with the establishment clause on the grounds that they remove barriers to "free exercise" by religious pacifists. See United States v. Seeger, 326 F.2d 846, 851-52 (2d Cir. 1964) (by implication); United States v. Jakobson, 325 F.2d 409, 414-15 (2d Cir. 1963). However, as Judge Friendly remarked, "under present day thinking as to the First Amendment, a statute could scarcely be defended on this score if it protected 'the free exercise' of only a few favored religions or preferred some religions over others without reasonable basis for doing so." $325 \mathrm{~F} .2 \mathrm{~d}$ at 415.

61322 U.S. 78 (1944), cited with approval in Sherbert v. Verner, 374 U.S. 398, 407 (1963), and United States v. Seeger, 85 Sup. Ct. 850, 863 (1965).

62322 U.S. at 88 . Three Justices dissented in part, arguing that instead of remanding to the circuit court for a hearing on other issues raised but not decided there, the district court's judgment of conviction should be reinstated. Mr. Justice Jackson dissented on the ground that it violated the first amendment even to let the jury decide 
It [first amendment freedom of religion] embraces the right to maintain theories of life and of death and of the hereafter which are rank heresy to followers of the orthodox faiths. Heresy trials are foreign to our Constitution. Men may believe what they cannot prove. . . . Man's relation to his God was made no concern of the state. He was granted the right to worship as he pleased and to answer to no man for the verity of his religious views.... When the triers of fact undertake that task, they enter a forbidden domain. The First Amendment does not select any one group or any one type of religion for preferred treatment. ${ }^{63}$

If the law may not inquire into the content of men's beliefs to determine their verity or reasonableness, it may be inferred that it is improper to use a particular belief, such as a belief in deity, as a test of religion. ${ }^{64}$ Using a standard based on the content of the belief in question would "establish" the selected beliefs over those rejected as not religious. Unorthodox or heretical beliefs could be excluded from the protection of the very amendment designed to protect such belief. The Court in Ballard was anxious to protect freedom of belief even for "teachings [which seem to be] nothing but humbug, untainted by any trace of truth."65 This can only be achieved if the content of a particular belief is eliminated as a criterion of religion.

\section{Religion Without God: The New Definition}

In United States $v$. Seeger, ${ }^{60}$ the Supreme Court reacted to the conflict between legislative intent to aid theists and the constitutional impediments to such discriminatory aid by distorting congressional intent to save the statute. ${ }^{67}$ No doubt the Court felt that to enforce the statute as written and to exclude nontheistic religious objectors ${ }^{88}$ from draft exemption would violate one or more of the prohibitions of the first

whether the accused actually believed what he preached. A determination of what is in fact believed cannot be separated from what is believable, he said, and such an inquiry is an impermissible tampering with freedom of belief which could lead to religious persecution.

63 Id. at 86-87.

64 This approach was taken in Fellowship of Humanity v. County of Alameda, 153 Cal. App. 2d 673, 315 P.2d 394 (1957).

65322 U.S. at 92 (Jackson, J., dissenting).

6885 Sup. Ct. 850 (1965).

B7 See notes 20-23, 32-36 supra and accompanying text. See generally Conklin, Conscientious Objector Provisions: $A$ View in the Light of Torcaso v. Watkins, 51 GEo. L.J. 252, 269-76 (1963).

68 Seeger professed "skepticism or disbelief in the existence of God," and his faith was a "belief in and devotion to goodness and virtue for their own sakes, and a religious faith in a purely ethical creed ...." 85 Sup. Ct. at 854 . 
and fifth amendments discussed above. ${ }^{69}$ But the Court did not expressly state the reason for its choice of this definition. Although the Court did not say that Torcaso forbids excluding nontheism from the category "religion," it modeled a definition which includes nontheists. Without stating that Ballard precludes the use of a particular belief as a criterion, the Court announced a definition in which the content of the beliefs in question is irrelevant. "[T] $\mathrm{T}$ he test of belief 'in a relation to a Supreme Being' is whether a given belief that is sincere and meaningful occupies a place in the life of its possessor parallel to that filled by the orthodox belief in God of one who clearly qualifies for the exemption."70

The Court did not suggest guidelines to help lower courts recognize religion when they see it, but the relevancy of certain factors might be inferred from the Court's brief discussion. Its reference to a "meaningful" belief may suggest a belief regarding the meaning of life; or, it may simply refer to a belief which is important to the person who holds it. That the belief must occupy a place in the life of its possessor parallel to the place that belief in God occupies in the life of the orthodox believer might suggest that, as in orthodox religions, a psychological commitment to and a system of moral practices resulting from the belief must be shown; on the other hand, this "factor" might be thought to require some sort of ritual practice, although this was not mentioned as a part of Seeger's "religion." The Court's statement that the draft statute's language encompasses a "faith to which all else is subordinate or upon which all else is ultimately dependent"71 denotes that a belief which is the exclusive or supreme system of ultimate beliefs of its adherent is religious; but, it does not make clear whether a belief must be the adherent's supreme belief system to be deemed religious.

Some light may be shed on the problems raised by the Seeger testjust what the "test" is and what characteristics it requires to qualify a belief as a religion-by an examination of Fellowship of Humanity $v$. County of Alameda.72 Although the Seeger opinion did not explicitly

69 Cf. $\hat{\mathrm{Mr}}$. Justice Douglas, concurring, id. at 865.

$70 \mathrm{Id}$. at 854.

71 Id. at 859 .

72153 Cal. App. 2d 673, 315 P.2d 394 (1957), hearing denied, I Civ. No. 17176 (Cal. Sup. Ct., Nov. 5, 1957) (4-3 decision), followed in Saint Germain Foundation v. County of Siskiyou, 212 Cal. App. 2d 911, 28 Cal. Rptr. 393 (1963). Cf. Washington Ethical Soc'y v. District of Columbia, 249 F.2d 127 (D.G. Cir. 1957).

The Tax Court neatly sidestepped defining religion in the recent case of Golden Rule Church Ass'n, 41 T.C. 719 (1964). A church's subsidiary corporation owned and operated several businesses to illustrate its belief that the Golden Rule can be applied in commerce. Because church members believed in economic equality, none of them 
refer to Fellowship, its "test" is quite similar to the one enunciated there. Furthermore, just as the Supreme Court in Seeger apparently did, the Fellowship court responded to what it considered to be a conflict between legislative intent to aid theism and the constitutional limitations on a permissible definition. There, the court strained to exempt a secular humanist group from property taxes under a state constitutional provision exempting "buildings ... used solely and exclusively for religious worship"73 because it felt that excluding the group from exemption might violate the first amendment on two grounds: (1) if the group were truly a religion, to exclude it would arbitrarily discriminate against nontheistic religions (a fifth amendment due process or fourteenth amendment equal protection question); ${ }^{74}$ and, (2) if the group were not a religion, to exclude it would be to read the state constitution as favoring religions over nonbelievers, and the court feared that this might violate the first amendment. ${ }^{75}$

If aiding all religions as religions is unconstitutional, the court reasoned, any legitimate exemption of religious organizations must also exempt all groups which " formulat [e] ... policies relating to good morals and respect for the law.' "76 Religious groups are exempt not "in the sense of dogma or doctrine" but because they perform a socially useful function cognizable by the state. ${ }^{77}$ The court stated that even if nontheism is not a religion in the common understanding of the term, the tax exemption could not stand unless its benefits were con-

owned any property as individuals; rather, the corporation owned all their property and distributed to each member a subsistence wage. Substantial financial losses were sustained for ten years. The court held the corporation's income to be tax exempt because it was "operated exclusively for religious purposes" under § 501(c) of the Internal Revenue Code. The court said: "It does not necessarily follow that we must accept all claims that activities are religious simply because those claims are sincere. Nor are we here required to essay a definition of religion. We are convinced that any constitutionally permissible definition would treat petitioners, together with the church, as religious organizations." 41 T.C. at 730 n.10. Cf. A. A. Allen Revivals, Inc., $22 \mathrm{CCH}$ Tax Ct. Mem. 1435 (1963).

73 Calif. Const. art. XIII, § I $1 / 2$.

74 "[A]ny type of statutory exemption that discriminates between types of religious belief-that discriminates on the basis of the content of such belief-would offend both the federal and state constitutional provisions." 153 Cal. App. 2d at 691-92, 315 P.2d at 406, citing Everson v. Board of Educ., 330 U.S. 1 (1947). The court said it would be arbitrary to exempt from taxation theistic cults "such as Father Divine's Peace Mission Movement, whose followers believe that Father Divine is God," but to exclude humanistic Unitarians or the plaintiff. 153 Cal. App. 2d at 691, 315 P.2d at 405.

75 See quotation from Everson, note 60 supra.

76153 Cal. App. 2d at 697,315 P.2d at 409.

77 Ibid. 
ferred without regard to religion as such, but were conferred on all groups which are socially beneficial in the way religious groups are. ${ }^{78}$

The court enunciated a twofold "objective" test to determine whether a group is a religion in the sense of being socially useful in the way traditional religions are. The test requires a finding of: (1) whether or not the belief occupies the same place in the lives of its adherents that orthodox beliefs occupy in the lives of their adherents; and, (2) whether the group conducts itself the way groups conceded to be religious conduct themselves.79 The court postulated four characteristics of every religion which, if present, would assure that the first requirement of the twofold test of religion had been met:

(1) a belief, not necessarily referring to supernatural powers;

(2) a cult, involving a gregarious association openly expressing the belief;

(3) a system of moral practice directly resulting from an adherence to the belief; and

(4) an organization within the cult designed to observe the tenets of belief.80

After enunciating this twofold test, with its "objective" requirements, the court proceeded to ignore it. In its zeal for "objectivity," it applied only one aspect of the dual test, that of behaving like a traditional religious group behaves. This was done because the court assumed that aid to religion as such is unconstitutional, yet it desired to uphold the tax exemption statute. It therefore had to establish criteria for determining the application of the statute that are not "peculiar to religious theory and practice in the technical sense." 81

78 Ibid. In this respect, the court construed the establishment clause according to the principle later suggested by Professor Kurland as a construction of both first amendment religion clauses, i.e., that government cannot use religion as a criterion for conferring a benefit but may aid religions if it does so by aiding all groups in a broader category which includes religions. The same result is achieved by construing religion so broadly as to include all groups which perform the same social function, as by consciously following Professor Kurland's suggestion of not using the term "religion" at all. See KuRLAND, RELigion and THE LAW (1962).

79 Because the Constitution forbids inquiry into "the validity of the beliefs held by the group involved," "the only valid test a state may apply in determining the tax exemption is a purely objective one. Once the validity or content of the belief is considered, the test becomes subjective and invalid. Thus, the only inquiry in such cases is the objective one of whether or not the belief occupies the same place in the lives of its holders that the orthodox beliefs occupy in the lives of believing majorities, and whether a given group that claims the exemption conducts itself the way groups conceded to be religious conduct themselves." 153 Cal. App. $2 \mathrm{~d}$ at 692,315 P.2d at 406 . The first part of this two-part test is identical to the Seeger test.

80153 Cal. App. 2d at 693,315 P.2d at 406.

81 Id. at.697, 315 P.2d at 409 . 
Besides applying only one aspect of the twofold test, the Fellowship court chose that part of its rule which was totally irrelevant to the problem of defining religion. The court said that the only legitimate reason for exempting religious organizations is to encourage groups which inculcate good morals. ${ }^{82}$ Even assuming that the court properly assessed constitutional imperatives presently required by the first amendment, ${ }^{83}$ the criteria applied by the court have no relation to social utility. Finding that the group's "activities are similar to those of theistic groups," 84 it held the Fellowship to be a religion. The court noted that the group had regular Sunday meetings at which members meditated, sang from group songbooks, collected contributions, heard speeches on matters of economic or political interest and listened to announcements. ${ }^{85}$ The court should have practiced what it preached and applied the test it articulated, rather than this hodge-podge of program notes. A meeting agenda is not a proper standard for distinguishing religions from nonreligious groups, even for the court's purpose of including all groups which perform the same socially useful function that religions do.

In fact, there is no relationship between the group's meeting agenda and its social utility. The local chapter of the National Association of Manufacturers, as well as the State University Football Boosters, the Girl Scouts and the DAR, may have weekly meetings at which the members meditate, sing songs from their songbooks, listen to a reading from a newspaper or magazine, hear a speaker on a subject of interest to the members (frequently of current economic or political interest, and often followed by questions and answers), collect contributions and hear announcements. ${ }^{86}$ Such meetings may even, unlike those of the Fellowship of Humanity, include a prayer to God. But these groups, in addition to not being religions in the ordinary sense, are also undeserving of tax exemption because they do not inculcate morality and respect for law in the way religions do, by means of an ultimate belief in and psychological commitment to what the religion views as The Right.

82 Although this is the rationalization usually used to justify tax exemption of religious organizations, it is probably not a valid proposition. Some religions advocate practices which are immoral to other religions; birth control is one example. Some religious groups may do more to undermine "established" moral norms and respect for the law-even to the extent of fostering racial intolerance-than they do to shore up these institutions. The Black Muslims may be an example of this type of religion. See Lincoln, The Black Muslims in America (1961); Sostre v. McGinnis, 334 F.2d 906, 909 (2d Cir. 1964); Cooke v. Tramberg, 43 N.J. 514, 205 A.2d 889 (1964).

83 See discussion following note 109 infra.

84153 Cal. App. 2d at 698,315 P.2d at 410 .

$85 \mathrm{Id}$. at $678-79,315$ P.2d at $397-98$.

86 Paraphrasing item by item the court's account of the Fellowship's meetings, ibid. 
Although it applied the wrong test, the analytical approach of the Fellowship court is useful in determining whether a group is religious. The first part of the test articulated but not applied in Fellowship, and used by the Supreme Court in Seeger (although it apparently was unaware of the California decision), should be adopted as the legal definition of religion for all purposes. More important, however, than the "definition," are the required characteristics suggested in Fellowship. They put meat on the Seeger bones.

At least one unique characteristic of religions distinguishes them from other groups which approve of and teach respect for morality and law. It is the combination of faith and psychological commitment to the object of that faith, ${ }^{87}$ be it God, Nirvana or the Good Way of Life. All groups legitimately called religious have this in common: they address the ultimate questions of existence and attempt to cope with the unknowable. 88 Their particular answers to these questions are irrelevant legally. ${ }^{89}$ Because of the unknowable nature of these questions, the answers necessarily must be accepted on faith. Religion is a belief which answers these questions: its believers are psychologically committed to that answer as the truth,90 the good or the sacred; and it provides the sanction (be it God's rewards and punishments or pangs of conscience) for the morality it teaches. It is the combination of morality plus psychological sanction which makes religion the especially effective moral educator legislators intend to aid by granting to religious groups benefits not generally extended to social or philosophical discussion groups. Nontheism is within this concept of religion.

An individual or group belief is religious if it occupies the same place in the lives of its adherents that orthodox beliefs occupy in the lives of their adherents. Four characteristics should be present:

(1) a belief regarding the meaning of life;

(2) a psychological commitment by the individual adherent

(or if a group, by the members generally) to this belief;

87 "One such definition has described religion as 'ethics tinged with emotion' . . . . [W]e will use Paul Tillich's definition and say that a man is religious when he is ultimately concerned and on the basis of this concern makes an unconditional commitment." Hordern, Christianity, Communism AND History I5 (1954). But see Stahmer, Defining Religion: Federal Aid and Academic Freedom, 1963 RELIGION AND THE PUblic ORder 116, 128-31.

88 See Yinger, Religion, Society, AND the INDividual 9 (1957), quoted in Stahmer, supra note 87, at 122 n.18; see also discussion of Paul Tillich's definition of theology in Stahmer, supra at 129.

89 See discussion following note 61 supra.

90 Or, at least, are committed to it as the truth for them, or the truth as far as they can know it. 
(3) a system of moral practice resulting from adherence to this belief; and,

(4) an acknowledgement by its adherents that the belief (or belief system) is their exclusive or supreme system of ultimate beliefs. ${ }^{91}$

This test begins with belief, for surely it cannot be denied that this is the foundation of every religion. But belief alone is not enough; the elements of psychological commitment to and moral practices resulting from the belief distinguish religion from philosophy and other branches of intellectual speculation..$^{22}$ These elements also relate religion to the "proper governmental purpose" of furthering public morality involved in legislation benefiting religion..$^{93}$ It should be noted that this test does not require a cult or organization as does the Fellowship test; ${ }^{94}$ this is so that it can be applied both to groups and to individuals. Another reason for deleting reference to cult, organization, or ritual, is that such reference might lead to reliance on irrelevant aspects of the group's behavior as a test of religion. The test is designed to recognize the essential nature of religion and its psychological function for its adherents, and to avoid restricting the forms which future groups may choose for religious expression. ${ }^{95}$ Furthermore, this test does not require

91 In A. A. Allen Revivals, Inc., 22 CCH Tax Ct. Mem. 1435 (1963), the Commissioner conceded that the taxpayer was a religious organization, but the court, in dictum, discussed what made the group religious. One element was worship services and sacerdotal functions; this element is similar to the test actually applied in Fellowship of Humanity. The court also referred to the group's "doctrinal statement or profession of faith," the "faith, creed, and religious observance of thousands of people" which is based on that doctrine, and the fact that the group "represents to its adherents their form of worship." Id. at 1443. These three elements are very similar to the four elements of the test suggested by this comment.

92 "Religious belief arises from a sense of the inadequacy of reason as a means of relating the individual to his fellow-men and to his universe-a sense common to men in the most primitive and in the most highly civilized societies. It accepts the aid of logic but refuses to be limited by it. It is a belief finding expression in a conscience which categorically requires the believer to disregard elementary self-interest and to accept martyrdom in preference to transgressing its tenets." United States v. Kauten, 133 F.2d 703, 708 (2d Cir. 1943) (A. Hand, J.) (Emphasis added). See also discussion and authorities cited notes 87,88 supra and accompanying text.

93 This refers to morality in the broad sense of the term. A given religion might not reinforce the "accepted" or established morality currently in vogue, but it teaches its own morality, and its followers are dedicated to what in their view is the Right. Even if a particular religion does not reinforce the accepted morality, by testing it in the crucible of criticism and competition the public quest for the "best" morality is furthered.

94 The Seeger definition did not require an organization or cult because the 1940 draft statute eliminated the 1917 act's requirement of membership in a recognized pacifist sect. See Conklin, supra note 67, at 260-63, 269-70.

95 But see Weiss, Privilege, Posture, and Protection: "Religion" in the Law, 73 Yale L.J. 593, 604 (1964), discussed infra note 103. 
any particular belief as a criterion of religion; it requires only that the belief fulfill a certain psychological function. The broad inclusiveness of the test is required by constitutional doctrine, of which Ballard and Torcaso are examples, but the test's fourth element avoids the overly broad aspect of the Fellowship test that would classify the Girl Scouts as a religion. The suggested test requires that the system of belief be its adherents' supreme belief. This excludes such groups as the Masons and the Boy Scouts which teach morality and have a belief system, but one which co-exists with and is intended to be subordinated to members' primary belief systems, their religions.

Seeger should be read to require these four characteristics because they are necessary to distinguish that which must constitutionally be designated religion from what is generally not considered religion. The reference in Seeger to a "meaningful" belief should be viewed as requiring a belief regarding the meaning of life (the first element of the suggested definition). That the belief must occupy a place in the life of its possessor parallel to the place that belief in God occupies in the lives of orthodox believers should be read to require a psychological commitment to and a system of moral practices resulting from the belief (the second and third elements of the suggested definition). The Court's statement that the draft statute's language encompasses "a faith to which all else is subordinate or upon which all else is ultimately dependent" ${ }^{\prime 6}$ should be read to require that the belief be the adherent's supreme system of belief. This would correspond to the fourth element of the suggested definition, 'and is the only part of it which requires extending Seeger beyond the Court's express language.

It should be noted that the Seeger opinion does not coincide in all particulars with the definition suggested here. For example, the Court expressly disclaimed any inclusion of atheists in its discussion; it said that Seeger "adhere[s] to theism," and that "the question is not, therefore, one between theistic and atheistic beliefs." 97 The implication is that atheists are not religious. However, the Court's definition of theists is so broad that the only persons who might be called atheists are nihilists and those who have not considered the meaning of life sufficiently to have a belief regarding its meaning. Still, doubt regarding atheism remains because common usage of the term is much narrower than in Seeger. Under the definition suggested in this comment, however, it is clear that atheists (as that term is commonly understood), as well

9685 Sup. Ct. at 859.

97 Id. at 858. The Court did not state that the question was one between theistic and nontheistic beliefs. 
as sincere and consistent Epicureans, ${ }^{98}$ could be religious. The Court's ambivalence on this point is unnecessarily confusing. It is more consonant with common understanding of the term "Supreme Being" to include nontheism in the category "religion" than it is to define religion as requiring belief in a supreme being and then say that a purely ethical creed constitutes belief in a supreme being. The Seeger court was forced into such semantic contortions only because it desired to preserve the constitutionality of the statutory definition of religion. Seeger's result, not its language, ${ }^{99}$ should be referred to by courts construing "religion" in other statutes.

Criteria other than those of the test proposed here have been suggested. Some courts would require, among other things, that the group be open to whoever elects to accept its tenets. ${ }^{100}$ But this criterion would make the classification turn on the content and form of the beliefs and should therefore be rejected. For example, the Black Muslims preach hatred of the white race, and only Negroes can join their ranks or witness their rituals. ${ }^{101}$ Do the Muslims fail as a religion for this reason? A belief

98 See report of Mr. Justice Stewart's misgivings regarding Epicureanism as constituting religion at the oral argument of Seeger, 33 U.S.L. WEEK 3187-89 (U.S. Nov. 24, 1964).

99 Another problem with Seeger's language arises with regard to proof of whether the belief is religious. The Court, stating that "the claim of the registrant that his belief is an essential part of a religious faith must be given great weight" (85 Sup. Ct. at 863), placed too much emphasis on the defendant's characterization of his belief. Draft exemption, or any benefit conferred by a statute referring to religion, should not depend on whether the applicant uses the proper words such as "religious" and "spiritual," or on whether he is foolish enough explicitly to disavow belief in a relation to a supreme being. But see id. at 864 . Kauten was correct in applying the same broad test as Seeger's to deny exemption to one whose sincerely-held belief was, in law, philosophical or political, despite the defendant's claim that it was religious. The trier of fact must evaluate the applicant's beliefs according to the test suggested here to determine whether it meets the legal requirements for classification as religious.

100 See Masonic BIdg. Ass'n v. Town of Stamford, 119 Conn. 53, 174 Atl. 301 (1934).

101 See authorities cited note 82 supra.

This is not to suggest that a "religious" group which preaches hatred should be permitted to spread its venom unrestrained. The first amendment rights of groups conceded to be religious are not absolute, but operate within the bounds of "compelling state interests." Compare Sherbert v. Verner, 374 U.S. 398 (1963), prohibiting a state from denying unemployment compensation to a Sabbatarian solely because she refused Saturday work, with Reynolds v. United States, 98 U.S. 145 (I878), affirming the conviction for bigamy of a Mormon despite the fact that his religion advocated polygamy. Thus, even though Communism would probably qualify as a religion under the suggested test (see authorities cited in Stahmer, Defining Religion: Federal Aid and Academic Freedom, 1963 RELIGION AND THE PUBLIC ORDER 116, 129, to the effect that Communism is a religion; but see First Unitarian Church v. County of Los Angeles, 357 U.S. 545, 548 (1958) (Clark, J., dissenting)), its "free exercise" could be limited by the compelling interest of national security. Surely this is so if a state may prohibit members of snake-handling sects from practicing a central ritual of their faith in order to protect public safety and health. See cases cited note 13 supra. 
cannot be excluded from the category of religion because it is not universalist or because it preaches hatred; this would involve an impermissible discrimination on the basis of the contents of particular beliefs.

The suggested definition of religion is narrow enough to exclude groups generally not considered to be religions, but includes all groups and beliefs that must constitutionally be included as religions. Under the suggested test, Fellowship and Seeger would be decided just as they were. Both litigants would be held to be religious, but the test used to achieve this result would be a meaningful one, and one which would exclude groups such as Kiwanis and the Masons whom legislatures probably intend to exclude. This exclusion is at least relevant to establishment clause cases and is indispensible in free exercise cases. (Should it violate first amendment religious freedom to forbid a Mason to wear his fez in public or to prohibit Kiwanis from soliciting contributions on "Peanut Day"?) For this reason, it will more closely approximate legislative intention than any other which is constitutionally permissible. This definition should work equally well for purposes of tax exemption, privileges in the armed forces or prisons, draft exemption and the free exercise clause, although the policies sought to be achieved by tax exemption of religious organizations might be effected without the use of the word at all.102

102 This definition does, however, raise grave problems in the area of religion in public schools. The Supreme Court has held that praying and Bible reading in schools violate the establishment clause. See Abington School Dist. v. Schempp, 374 U.S. 203 (1963). Because Seeger derived his "religious" inspiration from Plato, Aristotle and Spinoza, do readings from these authors violate the establishment clause as Bible readings do? "Ritual" readings from what were heretofore considered "secular" sources such as "The American's Creed" are probably not permissible. Compare Board of Educ. v. Barnette, 319 U.S. 624 (1943), where the Court held that schools may not require students to salute the flag or pledge allegiance to it, with Schempp, supra, at 224-26. The permissibility of Bible reading as well as of reading from Aristotle or Thoreau probably depends on whether the students are indoctrinated with or merely "taught about" the authors' views. See Schempp, supra, at 224, where the Court distinguishes between use of the Bible "as an instrument of religion" and its use "as an instrument for nonreligious moral inspiration or as a reference for the teaching of secular subjects." Whether that line can be drawn in practice is doubtful. But assuming that it were constitutionally permissible to teach about religious ideas without inculcating them, if ethics can constitute religion (see the views of David Saville Muzzey, a leader of the Ethical Culture Movement, quoted with approval in United States v. Seeger, 85 Sup. Ct. 850, 862-63 (1965)), is it unconstitutional to teach moral values in public schools? If one is not to discriminate against theism by teaching the doctrines of nontheist religions to the exclusion of theist doctrine in public schools, the answer must be in the affirmative. Yet one doubts whether the courts would give such an answer; they have traditionally justified indirect aid to religion as furthering the proper public function of reinforcing public morality. Is this now to be invalid as establishing the ethical religion of The Public Morality? Anticipating the charge that its decision prohibiting Bible reading and prayer in school would establish "a "xeligion of secularism," the Supreme Court in Schempp merely said, without elucidation, that moral education is 


\section{A DEFINITION Is Necessary}

It has been suggested that no definition of religion should be attempted.103 One court said that it is unconstitutional for "a state ... to determine that a cause is not a religious one." 104 This position is unsupportable if read literally. Surely a court may constitutionally hold that a Masonic lodge, ${ }^{105}$ a social fraternity ${ }^{106}$ or an athletic club which seeks tax exemption as a religious organization does not come within that classification. It seems quite clear, as recently stated by the Tax Court, that "it does not necessarily follow that we must accept all claims that activities are religious simply because those claims are sincere."107

Reference to but a few recent decisions demonstrates that governmental classifications in terms of religion are constitutionally permissible, and that a definition is therefore necessary to delineate the scope of such

permissible as long as it is "nonreligious." 374 U.S. at 224, 225. This cryptic statement probably indicates that courts will strain imaginatively to avoid proscribing moral instruction as an establishment of religion. One thing appears certain: "The fact that there is absolutely no legal history and no legislative or judicial definition of 'moral and spiritual values' is clearly a sign that the controversies and the litigation about religion and public education have hardly begun." DRINAN, RELIGION, THE COURTS, AND Public Poligy 60 (1963).

103 One writer has commented that any definition would restrict the freedom of present and future religions to be what they wish to be. Weiss, Privilege, Posture, and Protection: "Religion" in the Law, 73 YALE L.J. 593, 604 (1964). Mr. Weiss overstates the problem. The law is flexible, changing to meet the people's needs. This comment demonstrates that yesterday's definition of religion is changing to fit today's need. See also Stahmer, supra note 101, at 131-33. Furthermore, some definitions may themselves be sufficiently fiexible to permit the necessary evolution of religious forms and institutions. This comment suggests such a definition.

104 Kolbeck v. Kramer, 84 N.J. Super, 569, 574, 202 A.2d 889, 892 (1964). A state university student and his family had long practiced faith healing but did not belong to a recognized sect. The court properly held that the school could not deny him admission because he refused to be vaccinated if it admitted Christian Scientists on that basis, because he had a bona fide religious belief and "the State or any instrumentality thereof cannot, under any circumstances, show a preference of one religion over another." Id. at 575-76, 202 A.2d at 893.

105 See Masonic Bldg. Ass'n v. Town of Stamford, 119 Conn. 53, 174 Atl. 301 (1934). 106 See Theta Xi Bldg. Ass'n v. Board of Review, 217 Iowa 1181, 251 N.W. 76 (1933). 107 Golden Rule Church Ass'n, 41 T.C. 719 (1964). See discussion supra note 72. In Murdock v. Pennsylvania, 319 U.S. 105 (1943), the Supreme Court held that a religious colporteur cannot constitutionally be included in an ordinance which imposes a license fee for canvassing, soliciting or peddling, and said: "Moreover, we do not intimate or suggest in respecting their sincerity that any conduct can be made a religious rite and by the zeal of the practitioners swept into the First Amendment." Id. at 109. But see United States v. Seeger, 85 Sup. Ct. 850 (1965), where the Supreme Court held one who had no belief regarding God to be "religious" as that term is used in the Universal Military Training and Service Act, and exempt from the draft. The Court said: "In such an intensely personal area, of course, the claim of the registrant that his belief is an essential part of a religious faith must be given great weight." Id. at 863 . 
legislation. In Seeger the Supreme Court defined "religious" in a statute exempting religious objectors from the draft without even suggesting that it is unconstitutional to exempt only religious objectors. In Zorach $v$. Clauson ${ }^{108}$ the Court held that a program whereby public school students were released from class to attend religious school while nonparticipating students remained in school did not violate the first amendment. Administration of this program requires a definition of what instruction is "religious" so as to excuse pupils who attend it.

A definition is clearly necessary to determine what groups are to receive an exemption if tax exemption of religious organizations is constitutional. Although the Supreme Court has never decided their constitutionality, ${ }^{109}$ it might be argued that the recent decision in First Unitarian Church v. County of Los Angeles ${ }^{110}$ implicity approved these laws which exist in all fifty states and the District of Columbia.111

108343 U.S. 306 (1952).

109 See Abington School Dist. v. Schempp, 374 U.S. 203, 230 (1963) (concurring opinion); Note, 58 Colum. L. REv. 417,419 (1958).

110357 U.S. 545 (1958), and companion case Speiser v. Randall, 357 U.S. 513 (1958). See also the opinion of Chief Justice Warren in Braunfeld v. Brown, 366 U.S. 599, 606 (1961), which impliedly approved of indirect tax aid to religious groups. Braunfeld upheld Sunday closing laws against the claim that they violate the free exercise clause when applied to orthodox Jews.

111 See General Finance Corp. v. Archetto, 176 A.2d 73 (R.I.), appeal dismissed for want of a substantial federal question, 369 U.S. 423 (1962), holding that property tax exemptions for religious organizations do not contravene the first amendment or state constitutional provisions that "no man shall be compelled to frequent or to support any religious worship, place ..." 176 A.2d at 76-77. Accord, Lundberg v. County of Alameda, 46 Cal. 2d 644, 298 P.2d 1, appeal dismissed for want of a substantial federal question sub nom. Heisey v. County of Alameda, 352 U.S. 921 (1956). See also discussion and cases cited in Paulsen, Preferment of Religious Institutions in Tax and Labor Legislation, 14 LAw \& Contemp. ProB. 144, 146-48 (1949), and in PFEFFER, Church, State and FreEdom 189 (1953). "[T] here seems to be no ground for believing that an assault on tax exemption of church property upon first amendment grounds would succeed today or in the foreseeable future." Van Alstyne, Tax Exemption of Church Property, 20 OHIO ST. L.J. 461, 506-07 (1959), cited with approval, Abington School Dist. v. Schempp, 374 U.S. 203, 301 n.77 (1963) (concurring opinion). Accord, PFEFFER, op. cit. supra, at 190; Sutherland, Due Process and Disestablishment, 62 HARv. L. REv. 1306, 1338 (1949), also cited in Schempp, supra.

The constitutionality of such exemptions is usually justified on the grounds that religious organizations are benefited not for the purpose of advancing religious dogma but to support the public welfare function they perform of inculcating morality and respect for the law. See, e.g., Fellowship of Humanity v. County of Alameda, 153 Cal. App. 2d 673, 696-97, 315 P.2d 394, 408-09 (1957); Trustees of the First Methodist Episcopal Church v. City of Atlanta, 76 Ga. 181, 191-94 (1886); cf. State ex rel. Anshe Chesed Congregation v. Bruggemeier, 97 Ohio App. 67, 75-76, 115 N.E.2d 65, 69 (1953). However, some religions may not fulfill this public function. See discussion supra note 82 . Some have suggested another constitutional basis for exempting churches from taxation. Professor Kauper believes it to be permissible as aiding the free exercise of religion. See Kauper, Church, State, and Freedom: $A$ Review, 52 Mrch. L. REv. 829, 836-37 (1954). See also Trustees of the First Methodist Episcopal Church, supra at 195-96. 
California's denial of tax exemption, pursuant to the state constitution, to several churches because they refused to answer questionnaires inquiring whether they advocated the violent overthrow of the government, was reversed by the Supreme Court. Although the Court was aware that the petitioners claimed tax exemption as religious organizations-Justices Douglas and Black thought that the basis of the decision should have been the protection of the appellants' religious freedomnot one of the opinions even suggested that tax exemption of property used solely for religious worship was in any way improper.

Even if this form of indirect aid to religion were eventually held to be unconstitutional as violating the establishment clause, religion would have to be defined in applying the free exercise clause to determine when an individual's right to practice his religion has been infringed. In Sherbert $v$. Verner ${ }^{112}$ the Supreme Court held unconstitutional a state's denial of unemployment compensation to a Seventh-Day Adventist who refused to accept otherwise "suitable employment" which would have required her to violate her religious scruples by working on Saturday. The Sherbert rule that states may not interfere with religious practices unless a compelling state interest cannot otherwise be achieved was applied in People $v$. Woody ${ }^{113}$ and In re Jenison..$^{114}$ In each of these cases the Constitution was held to require government to make a special accommodation based on religion in order to avoid interference with the free exercise of religion;115 in every such case a definition is necessary.

It might be thought that if the thesis suggested by Professor Kurland in his controversial book Religion and the Law were accepted as a proper construction of the first amendment religion clauses, a definition of religion would not be necessary. This is not so. Professor Kurland

112374 U.S. 398 (1963).

11361 Cal. 2d 716, 394 P.2d 813, 40 Cal. Rptr. 69 (1964) (reversing a narcotics conviction of members of The Native American Church who used peyote, a hallucinogen, in their religious ceremonies).

114265 Minn. 96, 120 N.W.2d 515, vacated and remanded in light of Sherbert $\mathrm{v}$. Verner, 375 U.S. 14 (1963), following Sherbert, 267 Minn. 136, 125 N.W.2d 588 (1963) (reversing the contempt conviction of a juror who refused to serve because to judge violated her religious principles). See also United States v. Hillyard, 52 F. Supp. 612 (E.D. Wash. 943), holding that a juror's refusal to serve because of her religious beliefs is a valid defense to a contempt proceeding.

115 "In short, I think our Constitution commands the positive protection by government of religious freedom-not only for a minority, however small-not only for the majority, however large-but for each of us." Sherbert v. Verner, 374 U.S. 398, 416 (1963) (Stewart, J., concurring) (Emphasis added.). Some courts have suggested that the first amendment requires prison administrators to permit inmates to practice their religions as freely as is consistent with prison discipline. See, e.g., Sostre v. McGinnis, 334 F.2d 906 (2d Cir. 1964); Williford v. California, 217 F. Supp. 245 (N.D. Cal. 1963) (dictum). 
argues that the first amendment should be read to prohibit all governmental classifications based on religion. ${ }^{116}$ However, it does not follow from this that there would be no need to construe the meaning of religion in statutes. Even if the Kurland thesis were accepted, 117 "judicial definition of what is religion or religious activity cannot be avoided."118 In the Kurland scheme release of public school children from class to permit them to attend religious school is invalid as a classification in terms of religion. But if children including those with nontheistic beliefs were released to receive instructions in spiritual, moral and ethical values, would this be a classification in terms of religion? Perhaps so if the definition of religion used in United States $v$. Seeger ${ }^{119}$ or that suggested in this comment are accepted. Thus, religion must be defined if only to determine when an impermissible classification in terms of religion has been made.

One might contend that there should be more than one definition, perhaps even a different definition for each context in which religion appears. Since the problem is one of statutory construction, this is permissible, but it is undesirable. There is a limited range within which definitions constitutionally may vary. Any definition must include all traditional religions and certain forms of nontheism as well, or violate the first amendment as favoring some religions over others ${ }^{120}$ and the fifth amendment as arbitrarily discriminating against some religions. ${ }^{121}$ Given the narrow range within which definitions may vary, a single definition is desirable if only to avoid the confusion that would accompany the use of more than one definition. Furthermore, legislative intent would probably be better served by a uniform definition since the effect, and probably the purpose, of all of these statutes is the

116 KURLAND, RELIGION AND THE LAW 18, 22 (1962).

117 The Kurland thesis has been met with less than universal acceptance. See, e.g., Kauper, Book Review, 41 TEXAs L. REv. 467 (1963); Konvitz, The Constitution or Neutral Principles?, 1963 Religion ANd THE Public ORDER 99; Mansfield, Book Review, 52 CALIF. L. REv. 212 (1964); Pfeffer, Religion-Blind Government, I5 STAN. L. REv. 389 (1963). See also Sherbert v. Verner, 374 U.S. 398 (1963), which is irreconcilable with the Kurland thesis.

118 Kauper, Book Review, 41 Texas L. Rev. 467, 471 (1963). Accord, Mansfield, Book Review, 52 CALIF. L. REv. 212, 215-16 (1964).

11985 Sup. Ct. 850 (1965). See also Torcaso v. Watkins, 367 U.S. 488 (1961) and text accompanying notes 31-36 supra.

120 See Torcaso v. Watkins, 367 U.S. 488, 495 (1961), for the Court's most explicit dictum to the effect that nontheism is religion within the contemplation of the first amendment. See also discussion of the establishment clause in text accompanying notes 59-60 supra.

121 See discussion in text accompanying notes $46-57$ supra. 
same-to confer a benefit upon religion in the form of a subsidy or to facilitate the free exercise of religion.

However, even if a court were to use different definitions in different contexts, the approach suggested in this comment should be used to select the proper definition in any given context. 